\title{
Pisatin Production by Tissue Cultures of Pisum sativum L.
}

\author{
By J. A. BAILEY* \\ Department of Botany, University of Glasgow \\ (Accepted for publication 4 March 1970) \\ SUMMAR Y
}

\begin{abstract}
Callus tissues of Pisum sativum produced the phytoalexin pisatin when grown in axenic culture. Coconut milk, which was in the culture media, induced pisatin formation in pea leaf discs. Cultures which had been established for over 18 months showed a marked reduction in the ability to produce pisatin. Pisatin inhibited the growth of pea callus at low concentrations ( 5 to $10 \mu \mathrm{g} . / \mathrm{ml}$.), and may control callus tissue initiation and cellular necrosis during host-fungus interactions.
\end{abstract}

\section{INTRODUCTION}

The resistance of plant cells to fungal invasion appears to be explained, at least in part, by production of fungitoxic compounds following infection. Two major problems in investigating this possibility are: (i) that mechanical barriers must often be overcome by artificial means, as when storage fruits are inoculated with spore suspensions, thereby altering the metabolism of the tissue; (ii) that the amount of infected tissue differs in resistant and susceptible reactions. Measurements obtained from extracted plant material may indicate that the concentration of fungitoxic compounds is greater in rotted tissue, where large amounts of tissue are affected, than in resistant tissue, where only a few cells are affected. Precise conclusions can be made only when the amounts of tissue affected by the invading fungus can be determined.

Tissue cultures provide large volumes of actively dividing cells growing in a controlled chemical and physiological environment, and can be exposed to fungi without prior treatment to remove mechanical barriers. Large numbers of cells can be brought into contact with the fungal inoculum, thus enabling the number of cells affected by a nonpathogen to be similar to the number affected by a pathogen.

It is not yet known whether it is valid to compare the reaction of intact plant cells with that of similar cells from tissue culture. Ingram \& Robertson (1965) and Ingram (1967) showed that callus cultures from potato tubers exhibited the same R-gene resistance to Phytophthora infestans as the intact tubers from which they were derived. Robertson et al. (1968) demonstrated that this inhibition was due to phenolic acids produced after infection. However, Tomiyama et al. (I968) implicated the phytoalexin rishitin in R-gene resistance of potato tubers. Rishitin was not detected in tissue culture supernatants (Robertson et al. I968). Saad \& Boone (I966) reported that tissue cultures from the leaf and the petiole of apple shoots of cultivars either resistant or susceptible to Venturia inaequalis did not support the growth of this fungus.

Pisatin, a phytoalexin produced by various tissues of Pisum sativum, is believed to be

* Present address: Department of Botany, Imperial College of Science and Technology, London, S.W.7. 
responsible for the resistance of $P$. sativum to nonpathogenic fungi (Cruickshank, 1963). In the present work, callus cultures were derived from the stem and root of $P$. sativum, with a view to investigating the production of pisatin by these tissues after inoculation with various fungi and the relationship of this to the subsequent disease production. However, it became clear from early experiments that pisatin was produced by these cultures without infection by fungi. Because an essential feature of the original phytoalexin concept of disease resistance is that the phytoalexin is not a normal metabolic product of plant tissues, this phenomenon was investigated more closely.

\section{METHODS}

Media. Cylindrocarpon heteronema was grown on Czapek Dox agar (Thom \& Raper, 1945). Two media were used for tissue cultures. Medium I: mineral salts and micronutrients: $\mathrm{Ca}\left(\mathrm{NO}_{3}\right)_{2} \cdot 4 \mathrm{H}_{2} \mathrm{O}, 288 \mathrm{mg}$.; $\mathrm{KNO}_{3}, 80 \mathrm{mg}$.; KCl, $65 \mathrm{mg}$.; $\mathrm{NaH}_{2} \mathrm{PO}_{4} \cdot 2 \mathrm{H}_{2} \mathrm{O}$, $21.5 \mathrm{mg}$.; $\mathrm{MnCl}_{2} .4 \mathrm{H}_{2} \mathrm{O}, 6 \mathrm{mg}$.; $\mathrm{ZnSO}_{4} .7 \mathrm{H}_{2} \mathrm{O}, 740 \mathrm{mg}$.; $\mathrm{H}_{3} \mathrm{BO}_{4}$, I. 5 mg.; $\mathrm{H}_{2} \mathrm{MoO}_{4}$, $0.0017 \mathrm{mg}$; $\mathrm{CuSO}_{4} .5 \mathrm{H}_{2} \mathrm{O}$, $0.02 \mathrm{mg}$; $\mathrm{FeCl}_{3}$, $3.1 \mathrm{mg}$.; $\mathrm{Na}_{2} \mathrm{EDTA}$, $0.8 \mathrm{mg}$.; vitamins and amino acids: aneurin hydrochloride, $0.1 \mathrm{mg}$.; pyridoxine hydrochloride, $0.1 \mathrm{mg}$.; nicotinic acid, $0.5 \mathrm{mg}$; glycine, 3.0 mg.; other additions: 2,4-dichlorophenoxyacetic acid, $6 \mathrm{mg}$.; coconut milk, $150 \mathrm{ml}$.; sucrose, $20 \mathrm{~g}$.; agar, when required, $6 \mathrm{~g}$.; glass distilled water to I litre. Medium II: as for medium I, plus yeast extract, I g. The stock cultures were maintained on $30 \mathrm{ml}$. of medium solidified with agar in $100 \mathrm{ml}$. Pyrex conical flasks at $26^{\circ}$ in a growth room illuminated with a single $40 \mathrm{~W}$ tungsten lamp. Experiments using liquid media were carried out in conical flasks incubated at $26^{\circ}$ in the dark in a shaking incubator rotating at $150 \mathrm{rev}$./min.

Establishment and maintenance of tissue cultures. Pea seeds were washed in $70 \%$ (v/v) ethanol for $5 \mathrm{~min}$. and then treated with $0.1 \%(\mathrm{w} / \mathrm{v})$ mercuric chloride for $10 \mathrm{~min}$. They were rinsed in ten changes of sterile water and placed on moist cotton wool in I00 ml. conical flasks which had previously been sterilized by autoclaving at $12 \mathrm{I}^{\circ}$ for $20 \mathrm{~min}$. The flasks were incubated at $15^{\circ}$ in the dark. After 4 days the seedlings were dissected. The final $\frac{1}{4}$ in. of the root was discarded and the next $\frac{1}{4}$ in. was placed on medium II in order to initiate callus growth. Similar seedlings were grown for a further nine days. Segments of stem $\frac{1}{4}$ in. long were obtained and placed on medium I in order to initiate callus growth. The callus tissues which were produced after 4 weeks were transferred to fresh media. The root callus tissues were very variable and three visually distinct clones were distinguished and established. These isolates were maintained on medium II. The calluses produced from pea stem were more uniform, and the clone established was maintained on medium $\mathrm{I}$.

The ability of several constituents of the tissue culture media to induce the formation of pisatin in intact plants was tested by floating $8 \mathrm{~mm}$. leaf discs on drops of test solution maintained in plastic Petri dishes with lids lined with moist filter paper. The concentration of pisatin in the diffusates was measured after $48 \mathrm{hr}$.

Pisatin concentration was measured spectrophotometrically. The callus culture filtrates and leaf diffusates were extracted with redistilled light petroleum (B.P. $40^{\circ}$ to $60^{\circ}$ ). The light petroleum fractions were evaporated to dryness at $40^{\circ}$ under vacuum, the residue redissolved in absolute ethanol $(5 \mathrm{ml}$.) and the extinction of the resulting solution measured between 200 and $380 \mathrm{~nm}$. The concentration of pisatin was calculated from the extinction at $309 \mathrm{~nm}$. (Cruickshank \& Perrin, 196r). 
Preparation and purification of pisatin. Drops of a culture filtrate of Penicillium expansum were placed on pea pod endocarps. The diffusates were collected after $72 \mathrm{hr}$ and pisatin was obtained by extracting with light petroleum. The pod tissue was macerated in $90 \%(\mathrm{v} / \mathrm{v})$ ethanol, and after filtration the ethanol was removed under vacuum at $40^{\circ}$ and the aqueous fraction extracted with light petroleum. The pisatincontaining fractions were bulked and the ether soluble material was chromatographed on I mm. silica gel plates developed in chloroform. A distinct band $\left(\boldsymbol{R}_{\boldsymbol{F}}=0.25\right)$ was detected with ceric sulphate reagent (ceric ammonium nitrate, $\mathrm{I} \%(\mathrm{w} / \mathrm{v})$ in $4-\mathrm{N}-\mathrm{H}_{2} \mathrm{SO}_{4}$ ) and corresponded to pisatin. This band was eluted with ether and the high purity of the pisatin obtained was confirmed by infrared and ultraviolet spectrophotometry (Bailey, 1968).

Table I. Pisatin concentration in the supernatant of stem callus growing in medium $I$

Pisatin concentration assayed in $10 \mathrm{ml}$. of supernatant

\begin{tabular}{|c|c|c|}
\hline $\begin{array}{l}\text { Age of culture } \\
\text { (days) }\end{array}$ & $\begin{array}{l}\text { Vol. of } \\
\text { supernatant } \\
\text { (ml.) }\end{array}$ & $\begin{array}{c}\text { Pisatin } \\
\text { concentration* } \\
(\mu \mathrm{g} . / \mathrm{ml} .)\end{array}$ \\
\hline 0 & 150 & 0.00 \\
\hline 2 & 150 & 0.40 \\
\hline 4 & I50 & 0.40 \\
\hline 6 & 140 & 0.90 \\
\hline 8 & 140 & 0.80 \\
\hline IO & 140 & $1 \cdot 70$ \\
\hline 12 & 130 & 3.00 \\
\hline 14 & 130 & $6 \cdot 60$ \\
\hline 16 & 130 & $7 \cdot 50$ \\
\hline I 8 & 120 & $6 \cdot 80$ \\
\hline 20 & 120 & $7 \cdot 40$ \\
\hline 22 & 120 & $6 \cdot 50$ \\
\hline 24 & IIO & 6.80 \\
\hline 26 & IIO & $8 \cdot 30$ \\
\hline 28 & IIO & $6 \cdot 10$ \\
\hline 38 & 100 & 5.50 \\
\hline
\end{tabular}

\section{RESULTS}

Production of pisatin by young stem callus

Callus was grown for 29 days on solid medium I. A complete callus from each flask was used as inoculum into $250 \mathrm{ml}$. Pyrex conical flasks containing $150 \mathrm{ml}$. of liquid medium I. Twelve flasks were divided into three samples each containing four replicates. The pisatin concentration in $10 \mathrm{ml}$. of supernatant removed from each replicate was measured alternatively every 6 days, i.e. one sample was assayed on days $0,6,12,18$, etc. The results are shown in Table $\mathrm{I}$. They demonstrate that sterile callus produced pisatin when grown in liquid medium. During the initial 8 days after the callus was transferred into liquid medium, only small traces of pisatin were detected in the supernatant. During the following I 2 days pisatin was produced rapidly, and thereafter the pisatin detectable in the supernatant declined slowly.

To determine whether this production of pisatin was due to the presence of chemicals 
in the nutrient medium which themselves could induce pisatin formation, various constituents of the medium were tested for ability to induce pisatin synthesis in pea leaf discs. The results are shown in Table 2. Coconut milk induced the formation of the greatest amounts of pisatin; the remainder did not induce pisatin levels appreciably above those produced in distilled water.

Table 2. Pisatin concentration in diffusates obtained from pea leaf discs after $48 \mathrm{hr}$

Pisatin was assayed in $5 \mathrm{ml}$. of diffusate.

\begin{tabular}{lc}
\multicolumn{1}{c}{ Treatment } & $\begin{array}{c}\text { Pisatin } \\
\text { concentration } \\
(\mu \mathrm{g} . / \mathrm{ml} .)\end{array}$ \\
Medium II & $28 \cdot 8$ \\
Coconut milk (I5\%, v/v) & $24 \cdot 5$ \\
2,4-D (6 mg./.) & $9 \cdot 2$ \\
Vitamin solution* & $9 \cdot 2$ \\
Sucrose (2\%, w/v) & $9 \cdot 2$ \\
Inorganic stock solution $\dagger$ & $7 \cdot 8$ \\
Distilled water & $7 \cdot 8$
\end{tabular}

* The vitamin solution consisted of aneurin hydrochloride, 0.I mg.; pyridoxine hydrochloride, $0.1 \mathrm{mg}$.; nicotinic acid, $0.5 \mathrm{mg}$; and glycine, $3.0 \mathrm{mg}$. in I litre distilled water.

$\dagger$ The inorganic stock solution consisted of the 'mineral salts and micronutrients' listed under 'media' in I litre distilled water.

Table 3. Pisatin production by four culture lines of pea tissue culture

Results are the average of four flasks.

$\begin{array}{lccc} & \text { Results are the average of four flasks. } & \begin{array}{c}\text { Pisatin } \\ \text { concentration of } \\ \text { supernatant } \\ (\mu \mathrm{g} . / \mathrm{ml} .)\end{array} \\ \text { Culture line } & \text { Medium } & \begin{array}{c}\text { Dry wt } \\ \text { (g.) }\end{array} & 3.0 \\ \text { Pea root A } & \text { II } & 0.0782 \pm 0.0039 & 8.3 \\ \text { Pea root B } & \text { II } & 0.1113 \pm 0.0035 & 24.0 \\ \text { Pea root C } & \text { II } & 0.0946 \pm 0.0042 & 4.1 \\ \text { Pea stem } & \text { II } & 0.1313 \pm 0.0049 & 3.4 \\ \text { Pea stem } & \text { I } & 0.0976 \pm 0.0074 & \end{array}$

Pisatin production by various culture lines of Pisum sativum

The four culture lines of pea callus which had been established for 18 months were tested for ability to produce pisatin in liquid media. The root cultures were grown as callus on medium II for 28 days; the stem culture on medium I for 28 days. The entire calluses were transferred to $100 \mathrm{ml}$. Pyrex flasks containing $40 \mathrm{ml}$. of either medium I or medium II and incubated for 38 days. Pisatin was produced by all the callus cultures (Table 3 ); the amounts produced by these visually distinct culture lines differed markedly. Although yeast extract stimulated tissue growth, it did not affect the yield of pisatin.

The amount of pisatin produced by a given culture tended to decrease the longer the culture had been established: the pea stem culture shown in Table 3 had previously produced over $9 \mu \mathrm{g}$. pisatin $/ \mathrm{ml}$. Fresh isolates were made from sections of young pea stem placed on solid medium, when callus cells formed on their surfaces. When sufficient callus tissue had been produced, the sections were divided into two equal parts; one part was transferred to fresh solid medium, the other was used to determine capacity to produce pisatin. The callus which was grown on the solid medium was 
divided after 35 days, and the process repeated. The decrease in pisatin production was confirmed. An average measurement of 16 flasks showed that callus which had undergone only one passage produced over $\mathrm{I} 4 \mu \mathrm{g}$. pisatin $/ \mathrm{ml}$. after 35 days, but after eight passages the amount produced had fallen to only $6.5 \mu \mathrm{g} . / \mathrm{ml}$. This decrease in pisatin production was associated with a visual change in callus type. The callus cells produced initially were slow growing and darkly pigmented; subculturing selected a faster growing lightly pigmented strain. Pea root culture C (Table 3), which was darkly pigmented, also produced large amounts of pisatin.

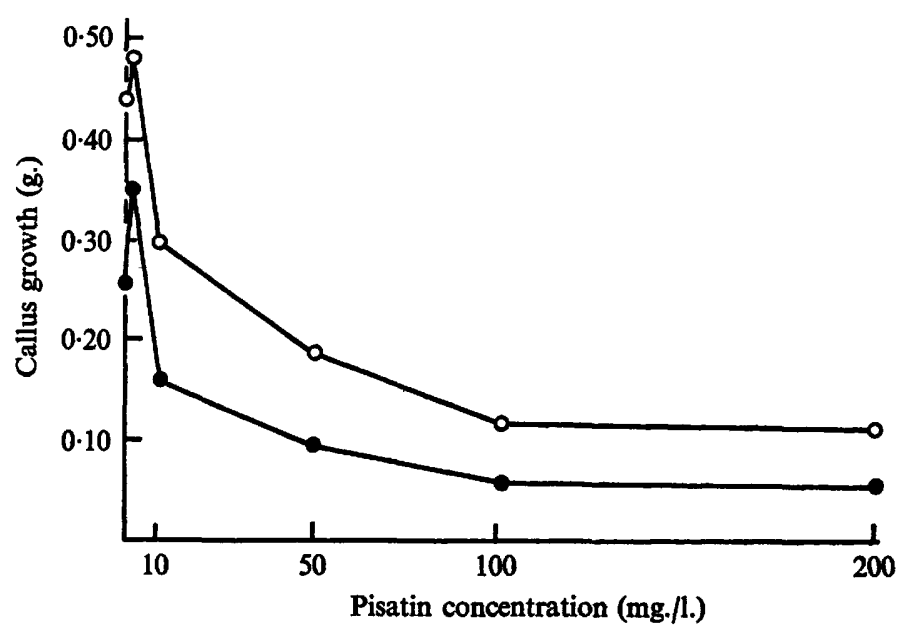

Fig. I. The effect of pisatin on the growth of pea stem callus. O-O, Dry weight; $-11^{-1} \times$ fresh weight. Callus was incubated for 20 days.

The effect of pisatin on the growth of stem callus in liquid medium

Pisatin was dissolved in ether, dispensed into flasks and the ether allowed to evaporate. Thirty $\mathrm{ml}$. of liquid medium I was added to each flask. An additional flask containing neither pisatin nor ether was also set up. Stem callus, which had been established for 2 years and was producing less than $2.0 \mu \mathrm{g}$. pisatin $/ \mathrm{ml}$. after 35 days was transferred to each flask, and measurements of growth were made after 20 days. The results (Fig. I) showed that pisatin caused a marked inhibition of callus growth at concentrations below $10.0 \mu \mathrm{g} . / \mathrm{ml}$. The calluses failed to fragment and were darkly pigmented, resembling newly established callus, whereas the unhibited calluses were finely divided and light brown in colour.

\section{DISCUSSION}

Pea callus cultures resembled pea leaf tissues. Callus cultures produced pisatin in axenic culture as a result of the presence of coconut milk, which, unlike most chemical agents known to induce pisatin synthesis, is non-toxic, and in fact was essential for growth of tissue cultures. After continued growth and the establishment of fastgrowing callus, the capacity of pea callus to synthesize pisatin decreased. A similar phenomenon was reported by Robertson et al. (1968). Ingram (1967) showed that, when a suspension of potato tuber callus was infected with Phytophthora infestans 
zoospores, the supernatant became increasingly toxic when tested against zoospore of $P$. infestans. In the initial work this toxicity was complete within 6 days. However, after continued growth of the callus for 3 years, toxicity was achieved only after Io days (Robertson et al. 1968). By careful selection one culture (pea root C) was obtained which continued to produce pisatin at high concentrations. In other work designed to compare the reaction of callus tissue with similar tissue from which it was derived, both apple fruit tissue and callus derived from the mesocarp of mature fruits failed to support the growth of microconidia of Cylindrocarpon heteronema. However, attempts to show the presence of a fungitoxic effect were only partially successful. A complete inhibition of spore germination on apple callus and in juice expressed from this callus was demonstrated. Similar effects could not be found using apple mesocarp tissue (Bailey, 1968). The use of apple callus may facilitate the identification of inhibitors which, perhaps due to their instability and/or localization, have not yet been detected in apple fruits.

Pisatin inhibited the growth of pea callus. Steward, Caplin \& Millar (1952) showed that explants of carrot grew more rapidly in liquid than on solid media. In the present work, frequent subculturing of the faster growing sectors resulted in the establishment of clones of faster growing cells. Newly established calluses appeared to grow more rapidly when transferred from solid to liquid media. Pisatin production by excised pea tissues probably restricts cellular growth so that, by repeatedly transferring the callus produced or by growing it in liquid media, callus tissue is selected which produces less pisatin; the concentration of pisatin in contact with the cells is thus reduced and rapid growth becomes possible.

During host-fungus interactions phytoalexin formation is associated with cellular necrosis (Cruickshank, 1963). Phaseollin production by Phaseolus vulgaris following inoculation with Colletotrichum lindemuthianum coincided with the occurrence of necrosis in both the hypersensitive reaction and in lesion formation (Rahe, Kuc, Chuang \& Williams, 1969; Deverall \& Bailey, 1969). Phytoalexin formation can occur without this associated necrosis, e.g. in the presence of coconut milk. However, in view of the phytotoxicity of pisatin shown in this work and by Cruickshank \& Perrin (I96I), it would appear that the possible regulatory role of phytoalexins in infected plants tissues should be further investigated.

This work was supported by the Science Research Council. The author wishes to thank Professor P. W. Brian, F.R.S., for his advice whilst the work was in progress and also during the preparation of the manuscript.

\section{REFERENCES}

Barley, J. A. (1968). Studies on Phytoalexins. Ph.D. Thesis, Glasgow University.

Cruickshank, I. A. M. (1963). Phytoalexins. Annual Review of Phytopathology 1, 35I-374.

Cruickshank, I. A. M. \& Perrin, D. (196I). Studies on phytoalexins. III. The isolation, assay and general properties of a phytoalexin from Pisum sativum L. Australian Journal of Biological Sciences 14, 336-348.

Deverall, B. J. \& Bailey, J. A. (1969). Phytoalexins. Journal of General Microbiology 59, xiv.

INGRAM, D. S. (1967). The expression of R-gene resistance to Phytophthora infestans in tissue cultures of Solanum tuberosum. Journal of General Microbiology 49, 99-108.

INGRAM, D. S. \& RoBertson, N. F. (1965). Interaction between Phytophthora infestans and tissue cultures of Solanum tuberosum. Journal of General Microbiology 40, 43I-437. 
Rahe, J. E., Kuć, J., Chuang, C.-M. \& Williams, E. B. (1969). Correlation of phenolic metabolism with histological changes in Phaseolus vulgaris inoculated with fungi. Netherlands Journal of Plant Pathology 75, 58-71.

Robertson, N. F., Friend, J., Aveyard, M., Brown, J., Huffee, M. \& Homans, A. L. (1968). The accumulation of phenolic acids in tissue culture pathogen combinations of Solanum tuberosum and Phytophthora infestans. Journal of General Microbiology 54, 26I-268.

SAAD, A. T. \& BOONE, D. M. (1966). Growth of Venturia inaequalis on apple callus tissues in vitro in relation to pathogenicity. Phytopathology 54, 905.

Steward, F. C., Caplin, S. M. \& Millar, F. K. (1952). Investigations on growth and metabolism of plant cells. I. New techniques for the investigation of metabolism, nutrition and growth in undifferentiated cells. Annals of Botany 16, 57-78.

Thом, C. \& RAPer, K. B. (1945). A Manual of the Aspergilli. London: Ballière, Tindall \& Cox.

Tomiyama, K., Sakuma, T., Ishizaka, N., Sato, N., Katsui, N., Takasugi, M. \& Masamune, T. (1968). A new antifungal substance isolated from resistant potato tuber tissue infected by pathogens. Phytopathology 58, I 1 5-1 16. 